\title{
Egy különleges késő avar kori övveret Szabadszállásról
}

\author{
${ }^{1}$ HORVÁTH M. ATTILA \\ 'Budapesti Történeti Múzeum Ős- és Népvándorlás kori Főosztály, H-1031 Budapest, Záhony utca 4. \\ e-mail: horvath.m.attila@gmail.com
}

Honváth, M. A.: A special Late Avar period belt mount from Szabadszállás

Abstract: Attila Horváth and Elvira H. Tóth excavated a relatively small Avar burial site of 68 graves at Szabadszállás between 1972 and 1975. Based on the findings the site was in use between the second half of the $7^{\text {th }}$ century and the middle of the $8^{\text {th }}$ century. Most of the graves have been robbed or with a few grave goods. However, during the 1974 works, a dual mount was found among the belt mounts with griffins of the no 34 undisturbed male burial. Only one similar piece is known in the whole country.

Keywords: cemetery, Late Avar period, belt mounts with griffins

\section{A lelöhely}

1972-ben Horváth Attila a Kecskeméti Katona József Múzeum akkori igazgatója leletmentést végzett Szabadszálláson a Batthyány utca1 8/b. szám alatti telken, ahol a tulajdonos egy keskeny sávban szőlőt akart telepíteni, és az aláforgatás során régészeti leleteket talált. A leletmentés során összesen tizenhárom sírt tártak fel, melyekből 7. századi avar leletanyag került elő. A sírok többsége kirabolt volt, míg a bolygatatlan sírok jobbára szegényes mellékletűek voltak. Ennek ellenére az előkerült leletek között aranyozott fülbevaló, vas- és bronzcsat és egy lulianus érem (331-363) is volt. ${ }^{2}$

1974-ben a szomszédos Batthyány utca 10. számú telken újabb sírok kerültek elő. A megelőző leletmentés során immár H. Tóth Elvira a telek déli szélén megnyitott $4 \times 70$ méteres szelvényben 45 sírt tárt fel, ${ }^{3}$ majd

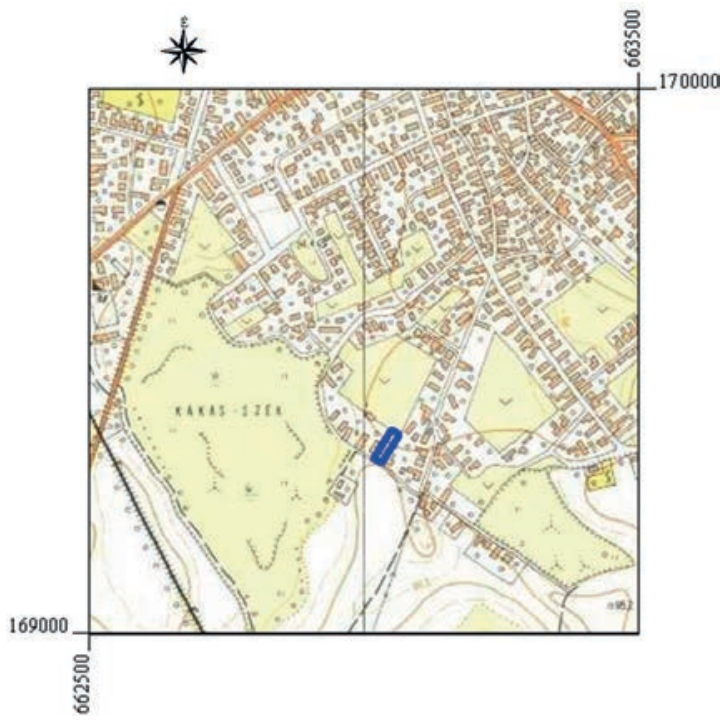

1. ábra. A lelöhely elhelyezkedése 1975-ben további nyolcat, melyekkel a temető sírszáma összesen 68-ra növekedett (1. ábra). ${ }^{4}$

$A$ jelentős részben bolygatott sírokból ezüst- és bronz lemezes, illetve pasztabetétes, négyzet alakú, fonatmintás övveret, valamint egy öntött bronz, griffes övgarnitúra mellett vas kések és tőrök, vas- és bronz csatok, egy vas fokosbalta, valamint szürke korongolt kiöntős, illetve hullámvonalas díszű edény, kézzel formált sírkerámiák, kisgömbös-, bogyós, és granulációval díszített gyöngycsüngős fülbevalók, orsógombok, üveg-, paszta-, és szemesgyöngyök, valamint egy vékony aranylemezből kivágott blank obulus kerültek elő. A sírokban emellett tekintélyes mennyiségü, ételmelléklet maradványainak tekinthető állatcsontok is voltak. Jellegzetes temetkezési szokásként figyelhették meg az ásatók az elhunytak részlegesen nyúzott birkabőrrel történt letakarását, illetve a sírok állatbőrökkel való bélelését.

A lelőhely az azóta községből várossá nőtt Szabadszállás dél-délnyugati szélén fekvő belterületen helyezkedik el, egy az első- és a második katonai felmérés térképein is jól megfigyelhető mocsaras, vízjárta területekből kiemelkedő homokdomb tetején (I. tábla 1-2.). Jóllehet a katonai felmérések óta a terület részben beépítésre került, a Batthyány utca a mai napig a település utolsó utcá-

A jelenlegi közigazgatási térképeken Batthyány János utcaként szerepel.

2 HoRváth 1973a, 66; HoRváth 1973b, 269; H. ТótH 1990, 163.

3 Н. То́тн 1975a, 83; Н. То́тн 1975b, 304; Н. То́тн 1990, 163.

4 Н. То́тн 1976а, 55; H. То́тн 1976b, 298; H. То́тн 1990,163.

5 EOV 1:10000 térképszelvény: 45-423; koordináták: $Y=663040, X=169344$, MBf.: 90 . Az adatokat Fábián István a BTM geodétája bocsátotta rendelkezésemre, amiért ezúton mondok köszönetet. 
ja, és a lelőhely földrajzi környezete jól megfigyelhető a mai közigazgatási térképeken is. A vizenyős területek a müholdfelvéteken is jól kivehetőek, és a ma már száraznak tekinthető részek friss szántásain még az egykori vízjárások nyomai is megfigyelhetőek.

A temető számunkra legérdekesebbnek tűnő sírja az 1974-es feltárások során került elő. A 34. számú bolygatatlan férfisír foltja a mai felszíntől mintegy 68 centiméter mélységben került elő, a vastag humuszréteg alatti sárga altalajban.

A sírgödör tájolása ÉNy-DK-i, É-tól Ny-ra 55․ Hossza 240 centiméter, szélessége 135-60 centiméter, mélysége 195 centiméter a feltáráskori felszíntől mérve. A csontváz sírban mért hossza az ujjpercekkel együtt, 188 centiméter volt, amiből arra lehet következtetni, hogy az elhunyt magassága életében 170 centiméter körül lehetett (2. ábra).

A sírgödör oldalfala lefelé szükült, 135 centiméter mélységben 80 centiméter, a sírfenék közelében 65 centiméter szélességúvé keskenyedett. A sírfeneket a sírgödör aljától mintegy 20 centiméter magasságtól indítva teknősen alakították ki. Koporsóra utaló nyomokat nem sikerült megfigyelni a bontás során, mint ahogy a temető egyetlen sírjában sem (II. tábla 1-2.). ${ }^{6}$

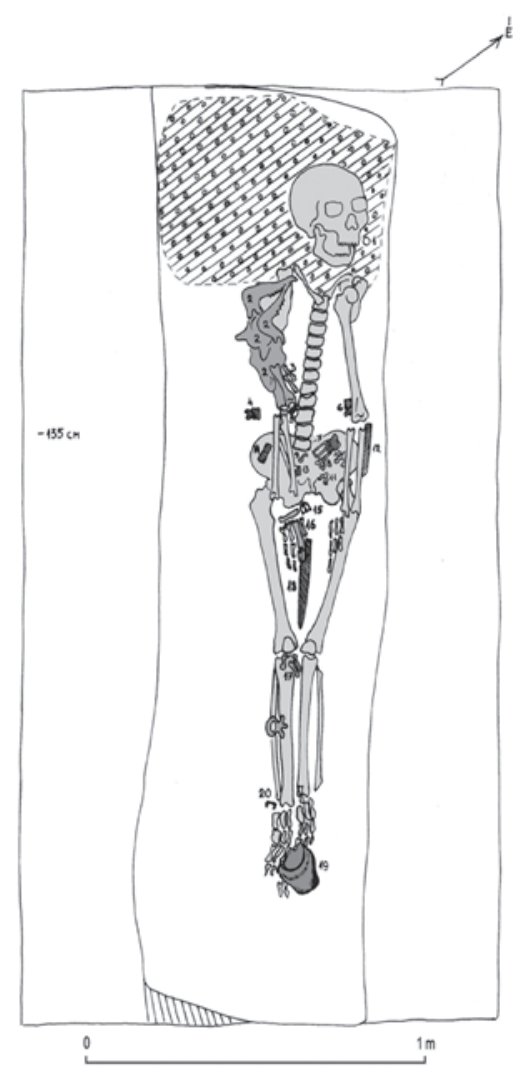

2. ábra. Szabadszállás-Batthyány

u. 10. A 34. számú sír

(H. Tóth Elvira rajza)

Az adultus(?) korú7 férfi nyújtott háton fekvő helyzetben eltemetett csontváza a sír tengelyétől kissé elmozdulva, a sírfenék teknős beásásának északkeleti szélén feküdt. A koponya kissé balra billent, de nem mozdult el, a helyén maradt az állkapoccsal együtt (2. ábra; III. tábla 1-2). A bal felkar befordult a gerinccsigolyák irányába. Az alkarok és a kézfejek párhuzamosan a medencelapáton, míg az alsó lábszárak szorosan összezárva, a lábfejek pedig kinyújtva nyugodtak. Mindebből arra lehet következtetni, hogy az elhunytat a sírbahelyezés előtt meglehetősen szorosan becsavarták valamilyen anyagba, feltehetően vászonba vagy bőrbe. A bőrbecsavarás esetén máshol pregnánsan jelentkező elszíneződések ${ }^{8}$ ebben a sírgödörben és a csontváz teljes felületén nem voltak megfigyelhetőek.

Nagyobb kiterjedésű szervesanyag maradványok maradtak viszont a sírgödör északnyugati végében, ahol a koponya alatti részen, mintegy $60 \times 50$ centiméter kiterjedésű sötét elszíneződés került elő. A csontváz és a koponya felszedése után ezen a részen 8-23 centiméter vastagságban sikerült megfigyelni ezt az elszíneződést, amelyet már H. Tóth Elvira is a halott számára elhelyezett párnaként értékelt (II. tábla 1.).

Egyéb szerves anyag maradványokat csupán a medence környékén figyelt meg az ásató, amelyet a ruházat vagy az öv maradványainak kell tekintenünk, és amelynek megmaradása feltehetőleg a deréktájon elhelyezett fémtárgyakkal hozható kapcsolatba (III. tábla 3.).

Ennek ellenére nem zárható ki, hogy a temető más sírjaihoz hasonlóan itt is előfordulhat a halott nyúzott állatbőrrel való letakarása. Amint azt már korábban is említettem, a temető sírjaiból meglehetősen nagy mennyiségú állatcsont került elő, mely maradványok részint ételáldozatokra, részint a halott védelmét, a földtől való megóvását is szolgáló részlegesen nyúzott állatbőrökkel (juh vagy kecske) való letakarására utalnak. Ez utóbbiak esetében rendszerint a törzs vagy emberi koponya közelében találjuk az állat koponyáját vagy az állkapcsot, míg a lábcsontok általában a vállak vagy karok mentén, illetve a comb vagy az emberi lábcsontok táján kerülnek elő, mint ebben az esetben is (2. ábra). ${ }^{9}$

\section{A sírból elökerült leletek}

1. Fülbevaló: karikája bronz, szögletes huzalból hajlított, töredékes, kerek lapos sötétkék gyönggyel (1. sz. melléklet, a koponya bal oldala mellett feküdt), Itsz.: 76.22.168. (V. tábla 2.)

6 Н. То́тн 1981, 178-179.

7 A temető antropológiai vizsgálatáról vagy annak eredményeiről egyelőre nincsen tudomásom.

8 H. TóтH 1984, 12. A Kunpeszér-Felsőpeszéri úti temető négy sírjában is sikerült H. Tóth Elvirának megfigyelnie, hogy az elhunytakat rendellenesen szorosan összekötözték és bőrbe csavarták. Ott azonban a nagy sírmélység és a magas talajvízszint miatt a bőranyagok erőteljes elszíneződését is meg lehetett figyelni. Az egyik ilyen sír esetében, melyet volt szerencsém magam felszedni, a csontokon és környezetükben lilás elszíneződések mutatkoztak, és feltehetően a cserzőanyagok kimosódása folytán a csontok mállékonnyá váltak, ami az egyéb sírokra nem volt jellemző.

9 Н. То́тн 1981, 179. 
2. Csüngősveret: öntött bronz, fekvő téglalap alakú áttört veret két szembenéző griffes ábrázolással, hat felerősítésre szolgáló lyukkal, csüngős tagja hiányzik, hátoldalán textillenyomattal (14. sz. melléklet, a jobb medencelapáton feküdt a jobb alkar orsócsontja alatt), m: $3,2 \mathrm{~cm}$, sz: $5,8 \mathrm{~cm}$, Itsz:: 76.22.173. (IV. tábla 2.)

3. Csüngősveret: öntött bronz, téglalap alakú áttört veret, jobbra néző térdelő griffes ábrázolással, négy felerősítésre szolgáló lyukkal, csüngős tagja áttört stilizált levéldíszes, hátoldalán textillenyomattal (4. vagy 6. sz. melléklet, a bal könyök belső oldalánál, illetve a jobb könyöktől kissé kijjebb feküdtek, a leírások alapján nem azonosíthatóak), m: 2,5 cm, csüngővel 5,0 cm, sz: 3,4 cm, Itsz.: 76.22.174. (IV. tábla 1.)

4. Csüngősveret: öntött bronz, téglalap alakú, áttört veret, jobbra néző térdelő griffel, négy felerősítésre szolgáló lyukkal. Áttört stilizált indadísze a csuklós szerkezetnél mereven derékszögben behajolva, hátoldalán textil lenyomatával (5. sz. melléklet, a jobb könyök belső oldalán, a gerinchez közel feküdt), h: 2,5cm, sz: 3,3 cm, Itsz.: 76.22.175. (IV. tábla 4.)

5. Csat: öntött bronz, trapéz alakú csat, pecke felül középen profilált díszű, áttört lapos indás csatteste csuklós szerkezettel kapcsolódik a csatfejhez (7. sz. melléklet, a bal medencelapáton feküdt), h: 8,4 cm, sz: 4,0-2,8 cm, Itsz.: 76.22.176. (IV. tábla 11.)

6. Lyukvédő (3 db): öntött bronz, patkó alakú, felülete bordázott, csavart díszű, három felerősítésre szolgáló lyukkal (8., 10-11. sz. melléklet, a jobb medencelapáton feküdtek, a 17. számú példányon egy vörösréz nittszeggel), h: 2,3 cm, sz: 2,3 cm, Itsz.: 76.22.177-179. (IV. tábla 7-9.)

7. Lyukvédő: öntött bronz, patkó alakú felülete bordázott, csavart díszű töredék, két felerősítésre szolgáló lyukkal, egyik szára hiányzik (9. sz. melléklet, a keresztcsonton feküdt), h:2,3 cm, Itsz.: 76.22 .180 . (V. tábla 10.)

8. Nagyszijvég: öntött, áttört bronz, négy jobbra néző, mindkét oldalon plasztikusan megmintázott griffes ábrázolással, melyet farkasfogas díszítésű keret fog össze. Szíjszorítóján talán griff ábrázolás jelzésszerűen, két felerősítésre szolgáló nittszeggel (12. sz. melléklet, a bal alsó karcsont külső élénél feküdt), h: $11,2 \mathrm{~cm}$, sz: 2,9-3,1 cm, v: 0,8 cm, Itsz.: 76.22.181. (IV. tábla 5.)

9. Veret: öntött, áttört, téglalap alakú griffes ábrázolású veret, négy felerősítésre szolgáló lyukkal és két nittszeggel. Hátoldalán öntésből származó textillenyomattal, felülete korrodált (13. sz. melléklet, a keresztcsonton, a bal alkar singcsontja alatt feküdt), h: $2,5 \mathrm{~cm}, \mathrm{sz:} 3,3 \mathrm{~cm}$, Itsz.: 76.22 .182 . (IV. tábla 6.)

10. Csüngősveret: öntött bronz, téglalap alakú áttört veret, jobbra néző térdelő griffes ábrázolással, négy felerősítésre szolgáló lyukkal, három nittszeggel. Csüngős tagja áttört stilizált levéldíszű, csuklós szerkezettel kapcsolódik a verethez. Hátlapján öntésből eredő textil lenyomattal (4. vagy 6. sz. melléklet, a bal könyök belső oldalánál, illetve a jobb könyöktől kissé kijjebb feküdtek, a leírások alapján nem azonosíthatóak), h: 5,1cm, sz: $3,3 \mathrm{~cm}$, Itsz:: 76.22.183. (IV. tábla 3.)

11. Vascsat: töredékes, szögletes pecke és karikájának egy része hiányzik (15. sz. melléklet, a két combcsont között, a kés felett feküdt), Itsz.: 76.22.184. (V. tábla 3.)

12. Vaskés: vasoxiddal átitatott fa tok maradványaival (18. sz. melléklet, a két combcsont között feküdt), h: 17,5 cm, sz: 2,2 cm, Itsz.: 76.22.187. (V. tábla 1.)

13. Vastöredék: ismeretlen rendeltetésű vastöredék vasoxiddal átitatott textillenyomattal (20. sz. melléklet, a jobb boka külső élénél feküdt), Itsz.: 76.22.188. (V. tábla 4.)

14. Edény: sárgásszürke, durva, kézzel formált sírkerámia, enyhén kihajló pereme csipkézett, nyaka kissé behúzott, oldala ívelt, nyúlánk (19. sz. melléklet, a lábfejcsontok mellett került elő), m: 12,6 cm, átm: 8,8 cm, Itsz.: 76.22.189. (V. tábla 5.)

\section{Állatcsontok (2. ábra)}

Juh, $1 \mathrm{db}$ (2. sz. melléklet, a jobb alkar alatt került elö), Itsz.: 76.22.169.

Juh koponya és állkapocs, 3 db (2. sz. melléklet, a jobb karon került elő), Itsz.: 76.22.191.

Juh, 2 db (16. sz. melléklet, a két combcsont között), Itsz.: 76.22.185.

Szárnyas, 8 db (3. sz. melléklet, a jobb karon került elő), Itsz.: 76.22.186.

Ló csigolya, 1 db (17. sz. melléklet, a jobb alsó lábszáron feküdt), Itsz.: 76.22.192.

További állatcsontok: mellékletszámozás nélkül

Sertés, $9 \mathrm{db}$, Itsz:: 76.22.170.

Sertés, $1 \mathrm{db}$, Itsz:: 76.22.171.

Juh, $1 \mathrm{db}$, Itsz:: 76.22.172.

Bronzkarika: vékony huzalból hajlított fülbevaló(?), 1 db, Itsz.: 76.22.190.10

Amint arról már korábban is esett szó, a leletek elhelyezkedése alapján magam is elképzelhetőnek tartom, hogy más szabadszállási sírokhoz hasonlóan az elhunytat a sírbahelyezés után nyúzott állatbőrrel takarhatták

10 A tétel a sírlapon nem szerepel, egyéb leírás, méret nem található, fotója nincs. 


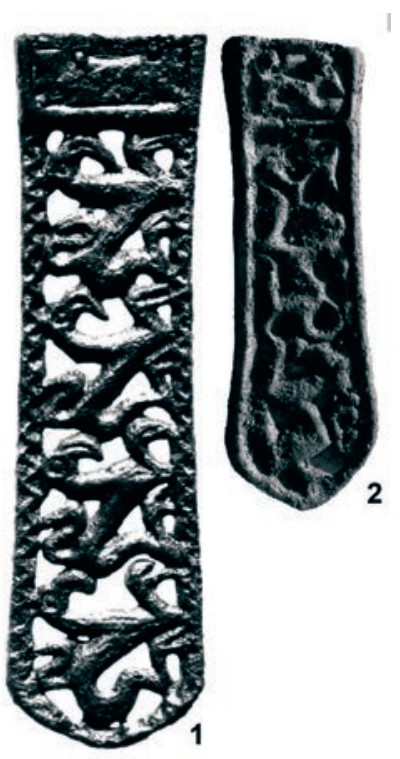

3. ábra. 1. Szabadszállás Batthyány utca 10. 34. sz. sír szíjvége; 2. Soroksár-Rétek 200. sz. sír szíjvége
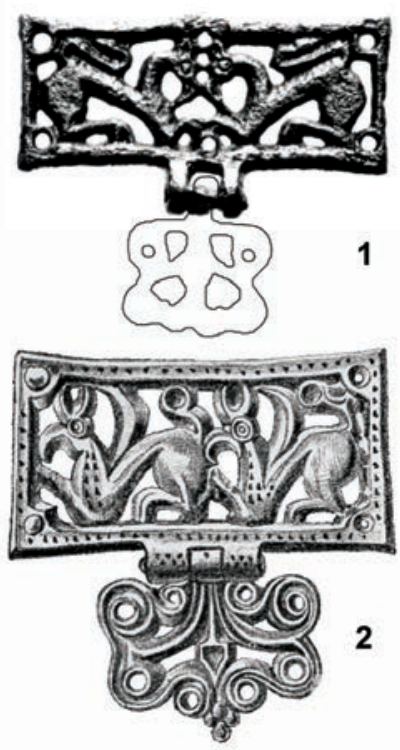

4. ábra. 1. A szabadszállási veret; 2. A szegedöthalmi veret (PULSZKY 1881. nyomán)

le a 34. számú sírban is. A sírfotókon (III. tábla 1-3.) és a sírrajzon (2. ábra 2-3., 16. mellékletek) is jól kivehető az elhunyt jobb felkarján heverő birka koponya és egyéb csontok maradványa, míg a karok alatt és a combcsontok között az állat egyes lábcsontjai helyezkedtek el. Természetesesen a részlegesen nyúzott birkabőr mellett ételáldozatok is kerültek a sírba, melyek maradványai szárnyas-, sertés- és lócsontok formájában maradtak ránk. A minden bizonnyal útravalónak szánt italt tartalmazó edényt a halott lábaihoz helyezték.

Ha a késeket és a tőröket nem számítjuk, fegyverek, de még nyílhegyek sem kerültek elő az egész temetőből, bár ez nem jelenti azt, hogy nem is lehettek. A 34. számú sírban azonban úgy tűnik eredetileg sem volt fegyver. Az elhunyt kése a combcsontok között feküdt, felette egy csattal (2. ábra; III. tábla 1., 3.).

A sír kétségtelenül legjelentősebb leletegyüttese a griffes övgarnitúra volt, amelyet a veretek elhelyezkedése alapján leoldva, többé-kevésbé a használatnak megfelelő helyzetben helyezhettek a sírba. Erre az említetteken kívül abból is lehet következtetni, hogy egyetlen veret sem került elő a medencecsont alóli részről. A leletek többsége a medencén, illetve némileg a fölött, a könyökök magasságában feküdt. Az övhöz összesen négy griffes veret tartozott, melyek közül három csüngős díszítésű volt (V. tábla 1., 3., 4., 6.). A nem túl igényes kialakítású veretek nem különösebben térnek el a térségben megszokottaktól. Keretük sima, a jobbra néző, térdeplő helyzetben ábrázolt griffek csőre erősen hangsúlyozott, farkuk a kerethez ívelődik, szárnyuk nincsen. Csüngőjük két elágazó és egy kiterebélyesedő indából áll, az egyik derékszögben behajlott. Az övre négy-négy rézszegeccsel erősítették fel őket, melyek közül csak néhány maradt meg eredeti helyén. A négy patkó alakú lyukvédő (melyek közül az egyik szára letörött, V. tábla 7-10.), kialakítása és vízszintes bordázású díszítése is átlagosnak mondható, számos leletegyüttesben találkozhatunk velük. Érdekes viszont, hogy nem került elő a sírból övforgó.

Az övcsat kialakítása már érdekesebbnek tűnik, a trapéz alakú csatfej, és a hozzá tartozó erősen profilált csatpecek egy pajzs alakú öntött bronz csattesthez csatlakozik, melynek felületén két vaskosabb, és két kisebb, egymástól elágazó lapos indadíszítés látható, melyeket egy erős, nyújtott „X” alakú borda választ el egymástól (V. tábla 11.). Ez a díszítésforma szintén nem idegen a korszak leletei között, példaként most talán csak a szebényi temető 51. sírjából, ${ }^{11}$ vagy a viszneki temető 81 . sírjából előkerült példányokat hoznám fel. ${ }^{12}$

A garnitúra szíjvége, amely a bal alkar külső oldalánál került elő már különlegesebb példánynak számít ( $V$. tábla 5.). A nyújtott pajzs alakú áttört veret mintázatát vonuló, vagy sorban álló griffek csoportja alkotja. A veret előlapján jobbra, a hátoldalon természetszerüleg balra néző, négy plasztikus állatalak kialakítása megegyezik az övveretek alakjaival. Kerete azonban a többitől eltérően farkasfog mintázatú. A korszak hasonló kialakítású, vonuló vagy sorban álló griffeket megjelenítő szíjvégeinek többségén leginkább a három griffalak ábrázolása az általános. Természetesen vannak ettől eltérő, gyakrabban két, vagy ettől több alakot ábrázoló példányok is. Ezek előfordulása azonban Fancsalszky Gábor szerint is igen ritka. ${ }^{13}$

\footnotetext{
11 GaRAm 1975, 78, fig. 6. 51.1., PI XI.6

12 ТÖRÖK 1975b, 334, fig. 7. 81. 1.

13 FANCSALSZKY 2007, 56.
} 
A szabadszállási szíjvég szíjszorítóján külön keretben elmosódott állatalak, az ásató szerint talán szintén egy griff látható. A szíjvégek kialakításakor sok múlik a készítő ügyességén is. Egy Soroksáron 2009-ben előkerült hasonló szíjvégen például csak két és fél griff fért el, viszont a köpűn jól kivehető egy hegyes orrú kis állat - esetleg kutya - alakja. ${ }^{14}$

Mindezek ismeretében, felmerül a kérdés, hogy mégis akkor mitől olyan érdekes ez a nem túl elegáns kivitelü, csaknem szokványosnak mondható övgarnitúra. A korábban említett négy griffes veret (három csüngős, egy csüngő nélküli) mellett volt egy ötödik példány is, amelynek csüngője talán még használójának életében elveszett. Maga a veret azonban csaknem egyedülállónak számít a griffes kultúrkörben (4. ábra 1., IV. tábla 2.).

A veret kivitele és készítési technikája megegyezik a többivel, azonban kissé alacsonyabb azoknál, szélessége viszont csaknem eléri a kétszeresüket és a középmezejében nem egy, hanem két griff található. Pontos párhuzamot nem sikerült fellelnem a korszak hazai, de még a határon túli területek leletei között sem. Egyetlen hasonló példányt ismerünk Szeged-Öthalomról, amely a 19. század végén került elö. A leleteket Pulszky Ferenc közölte az Archaeologiai Értesítő 1881-es számában. Pulszky azonban a leletek képes közlésén kívül csupán annyival foglalkozik, hogy mely veretek tartozhattak az ott bemutatott nagyszíjvéghez. A kettős veretet meg sem említi (4. ábra 2.). ${ }^{15}$

A szegedi veretek a rajzos tábla tanúsága szerint jóval mívesebbnek látszanak és díszítőelemeikben is gazdagabbnak tűnnek a szabadszállási leleteknél. Az rajz alapján talán ékvéséses keretezésú vereteken és a csattesten, jobbra néző szárnyas griffeket ábrázoltak, csakúgy mint a rovátkolt keretezésú szíjvégen is. A trapéz alakú csatkeret és a profilált csatpecek is igen hasonló a szabadszállási példányhoz. A szeged-öthalmi kettős vereten azonban a szíjvéghez hasonlóan a megszokott vonuló/sorban álló griffeket láthatjuk. Ezzel szemben a szabadszállási veret készítője a két griff szembefordításával egy szimmetrikus kompozíciójú múvet alkotott.

E két különleges veret felbukkanása azonban a kezdeti lelkesedés mellett számtalan, számomra meglehetősen nehezen megválaszolható kérdést vetett fel. Többek között azon tűnődtem, hogy vajon honnan vehették az ötletet, vagy milyen indíttatásból készítették őket? Személyes "művészi” ambíció, vagy valamilyen megrendelői igény nyomán készültek? Valamint azon is, hogy amennyiben volt ilyen szándék, vagy igény, akkor miért csak két ilyen példány készült, vagy ha készült több is, mi lehet az oka, hogy csak ezt a két példányt ismerjük az eddig előkerült számtalan leletegyüttesből?

Szóval Lacikám van min gondolkodni, és gondolom nem csak ez a két veret késztet majd gondolkodásra bennünket. Kívánom neked ezen a szép ünnepen, hogy még sokáig gondolkozzunk együtt, és vitassuk meg közösen az ötleteinket, mint eddig is.

Isten éltessen sokáig Laci!

\section{Összefoglalás}

1972 és 1975 között Szabadszálláson egy viszonylag kis létszámú, mindössze 68 sírból álló avar temetőt tárt fel Horváth Attila és H. Tóth Elvira.

A jelentős részben bolygatott sírokból ezüst- és bronz lemezes, illetve pasztabetétes, négyzet alakú, fonatmintás övveret, valamint egy öntött bronz griffes övgarnitúra mellett vas kések, és tőrök, vas- és bronz csatok, egy vas fokosbalta, valamint szürke korongolt kiöntős, illetve hullámvonalas díszú edény, kézzel formált sírkerámiák, kisgömbös-, bogyós, és granulációval díszített gyöngycsüngős fülbevalók, orsógombok, üveg-, paszta-, és szemesgyöngyök, valamint egy vékony arany lemezböl kivágott blank obulus kerültek elő. Az említett fokoson és tőrökön kívül fegyverek nem kerültek elö.

A sírokban emellett tekintélyes mennyiségú ételmelléklet maradványainak tekinthető állatcsontok is voltak. Jellegzetes temetkezési szokásként figyelhették meg az ásatók az elhunytak részlegesen nyúzott birkabőrrel történt letakarását, illetve a sírok állatbőrökkel való bélelését. A leletanyag nyomán a temetőt a 7. század második fele és a 8. század közepe közötti időszakban használhatták. Az előkerült sírok nagyobb részt rablottak, vagy csak igen szegényes mellékletúek voltak. Az 1974-es munkálatok során feltárt 34. számú bolygatatlan férfisír griffes veretei között azonban egy olyan kettős veret került elő, amelyhez csak egyetlen hasonló példányt ismerünk az országból.

Az övhöz összesen négy griffes veret tartozott, melyek közül három csüngős díszítésű volt. Négy patkó alakú lyukvédő, egy indadíszes csattestű, trapéz alakú bronz csat és egy vonuló griffeket ábrázoló szíjvég tartozott. Övforgó nem került elő.

Az ötödik veret azonban szokatlan módon két szembenéző griffalakot ábrázol. Magyarországról a formailag hasonló, de kompozíciójában némileg eltérő szeged-öthalmi leleten kívül más hasonló példányt egyelőre nem ismerünk.

14 HoRVÁtH 2010; HoRvÁTH 2017, 286-287, 295. kat. sz.: 1084.

15 Puıszky 1881, 151-152. A 151. oldalon látható rajztáblán a szeged-sövényházi lelet megnevezés látható, azonban ezt az elírást azóta már korrigálták, lásd ADAM 2002. I. 342. 01-06-570-10. tétel. 


\title{
A special Late Avar period belt mount from Szabadszállás
}

\author{
ATTILA M. HORVÁTH
}

Between 1972 and 1975 in Szabadszállás a relatively small Avar cemetery of only 68 graves was excavated by Attila Horváth and Elvira H. Tóth.

A significant amount of the graves were already damaged but silver- and bronze plated square belt mount with glass paste and weaved ornament; a cast bronze belt set with griffins, iron knives and daggers, iron and bronze buckles, a shepherd's axe of iron were found, as well as a grey wheeled spouted bowl and a vessel decorated with wavy lines, handmade grave ceramics, several types of bead-pendant earrings and pearls; and a blank obulus cut from a thin gold plate. There were no weapons besides the above mentioned axe and daggers.

There were a significant amount of animal bones in the graves that can be interpreted as the remains of food packed for the deceased. Researchers have identified a characteristic burial habit: the deceased were covered with partially skinned sheepskin and the graves were lined with animal skins. Based on the finds the cemetery was used between the $2^{\text {nd }}$ half of the $7^{\text {th }}$ century and the middle of the $8^{\text {th }}$ century.

In 1974, the intact grave of a male (No. 34) was uncovered that contained belt mounts with griffins, including a double piece with only one analogy known in Hungary. There was 5 griffin mounts belonging to the belt, 4 depicting griffins - out of those 3 with pendants. The fifth mount, however, unusually represents two opposing griffin forms. We do not know about such a form of Hungary, apart from the formally similar but somewhat different find of Szeged-Öthalom. There also were 4 horseshoe-shaped hole protectors, trapezoid bronze buckle decorated with floral ornaments, and the ending of the belt that depicts marching griffins. However, no propeller shaped belt mounts were found. 

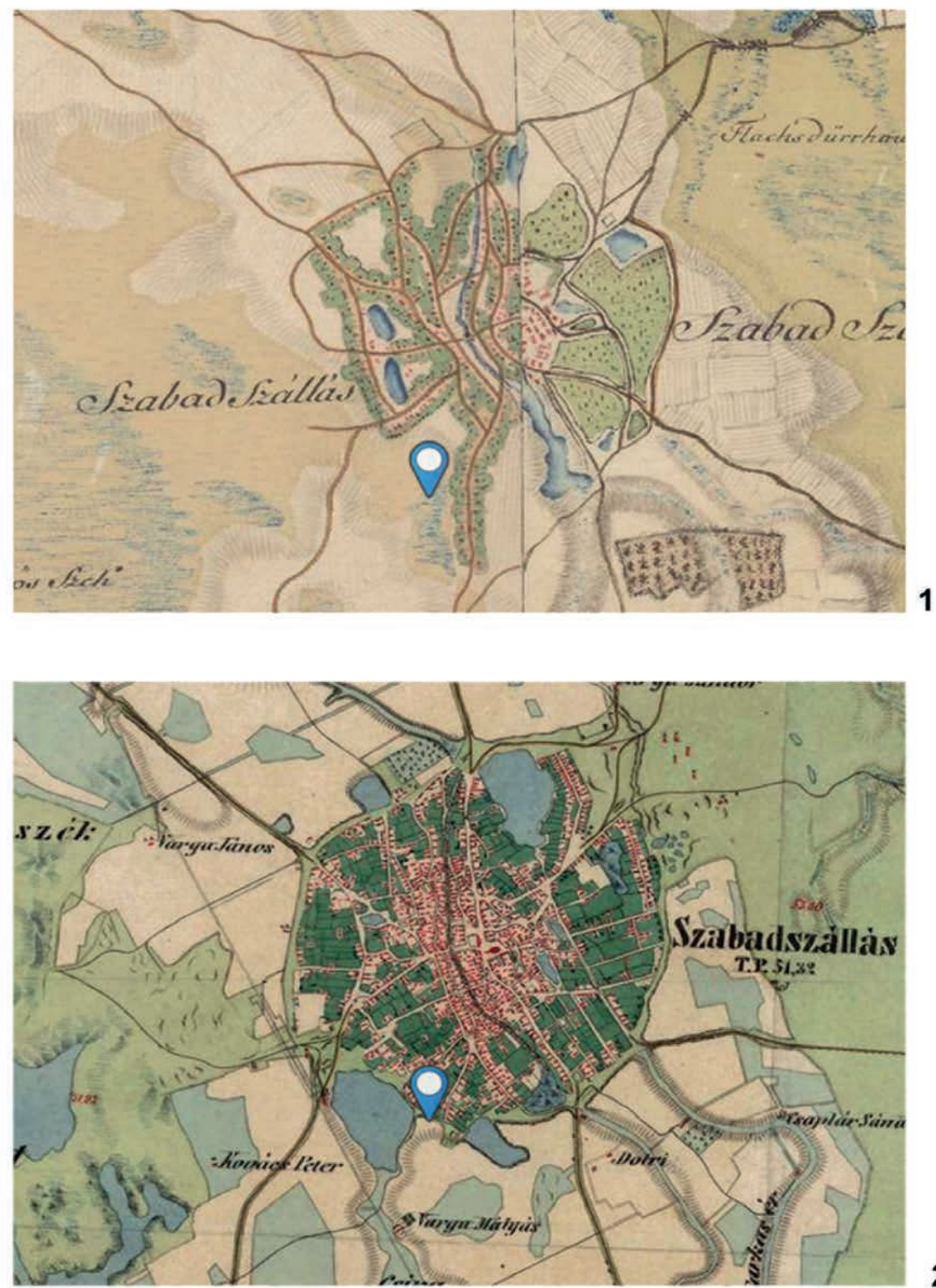

I. tábla. Szabadszállás-Batthyány utca 8b-10. lelöhely földrajzi környezete. 1. Első katonai felmérés; 2. Második katonai felmérés. (Forrás: www.mapire.eu, letöltés: 2018. január 26.) 


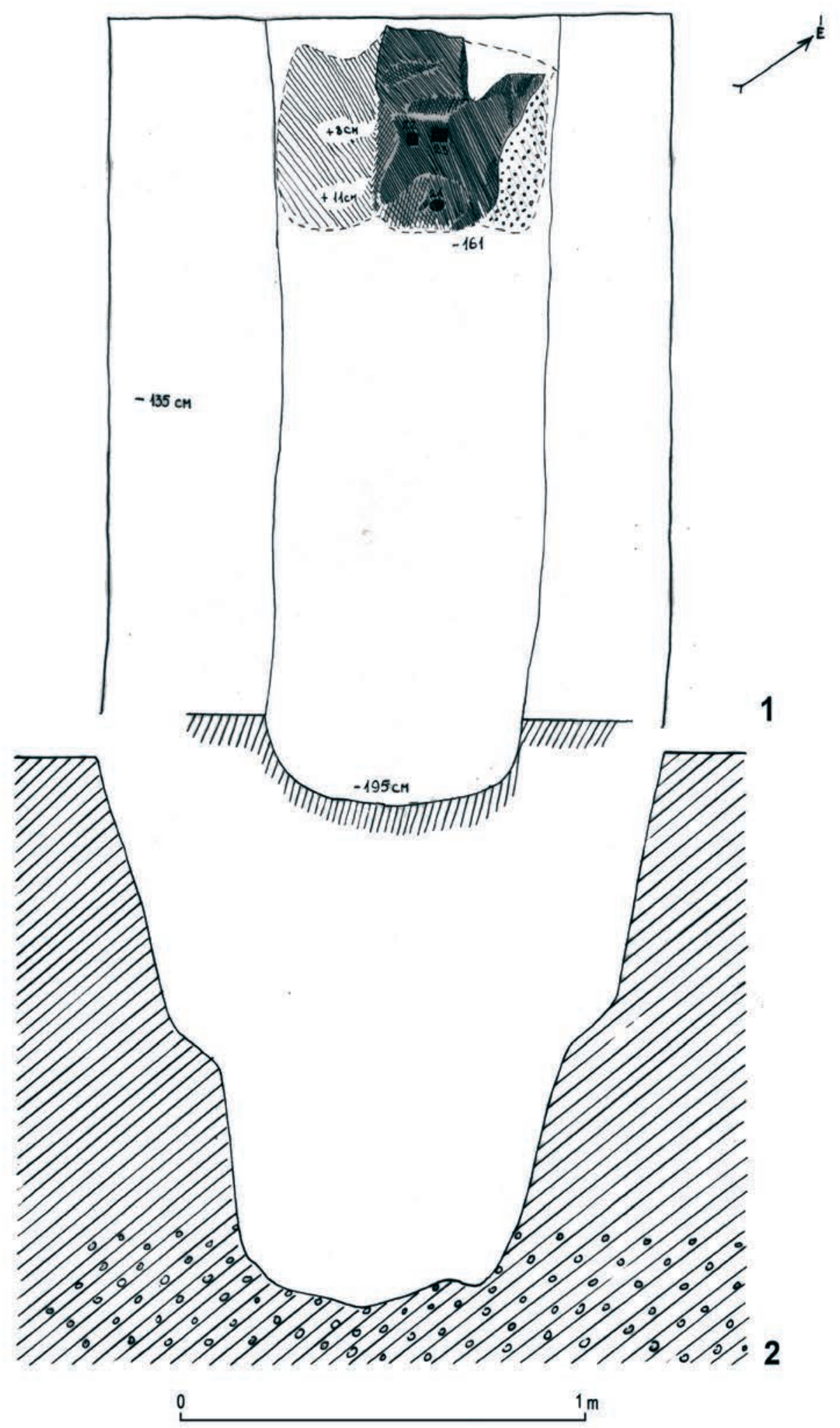

II. tábla. Szabadszállás Batthyány utca 10. A 34. számú sír. 1. a sírfenéken jelentkező szerves elszíneződések; 2. A 34. sír metszetrajza (H. Tóth Elvira rajzai) 

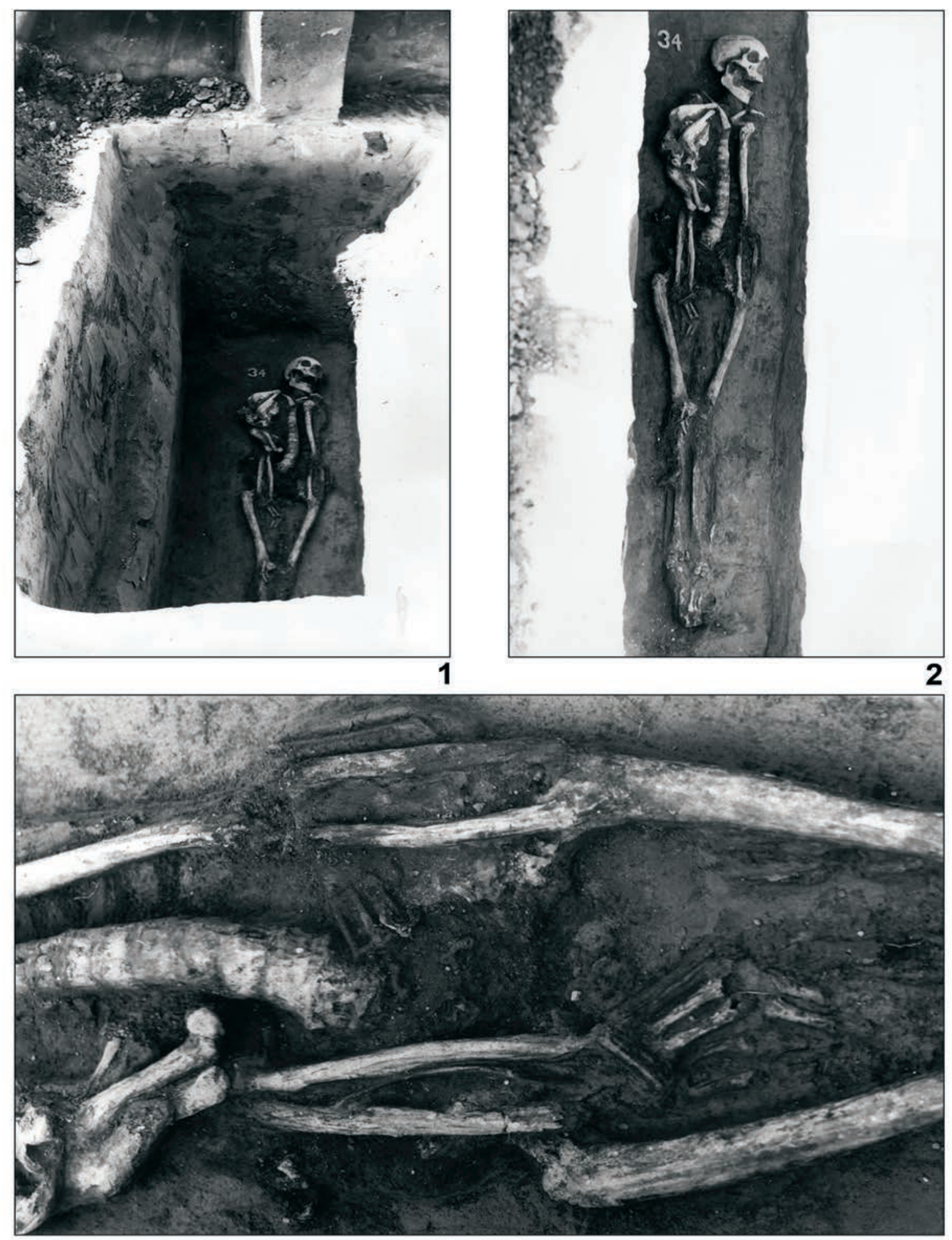

III. tábla. Szabadszállás-Batthyány utca 10. A 34. számú sír. 1-3. sírfotók 

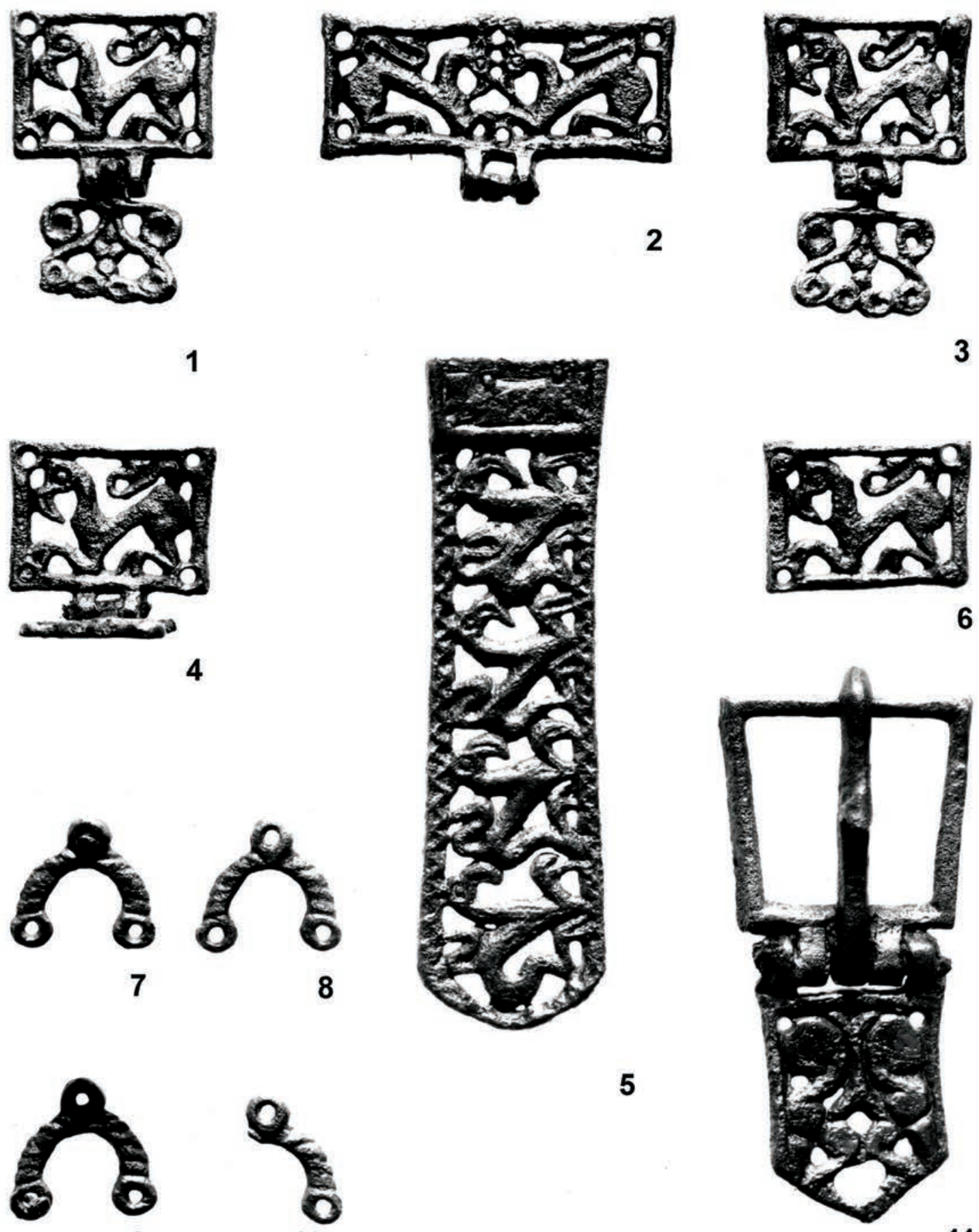

5
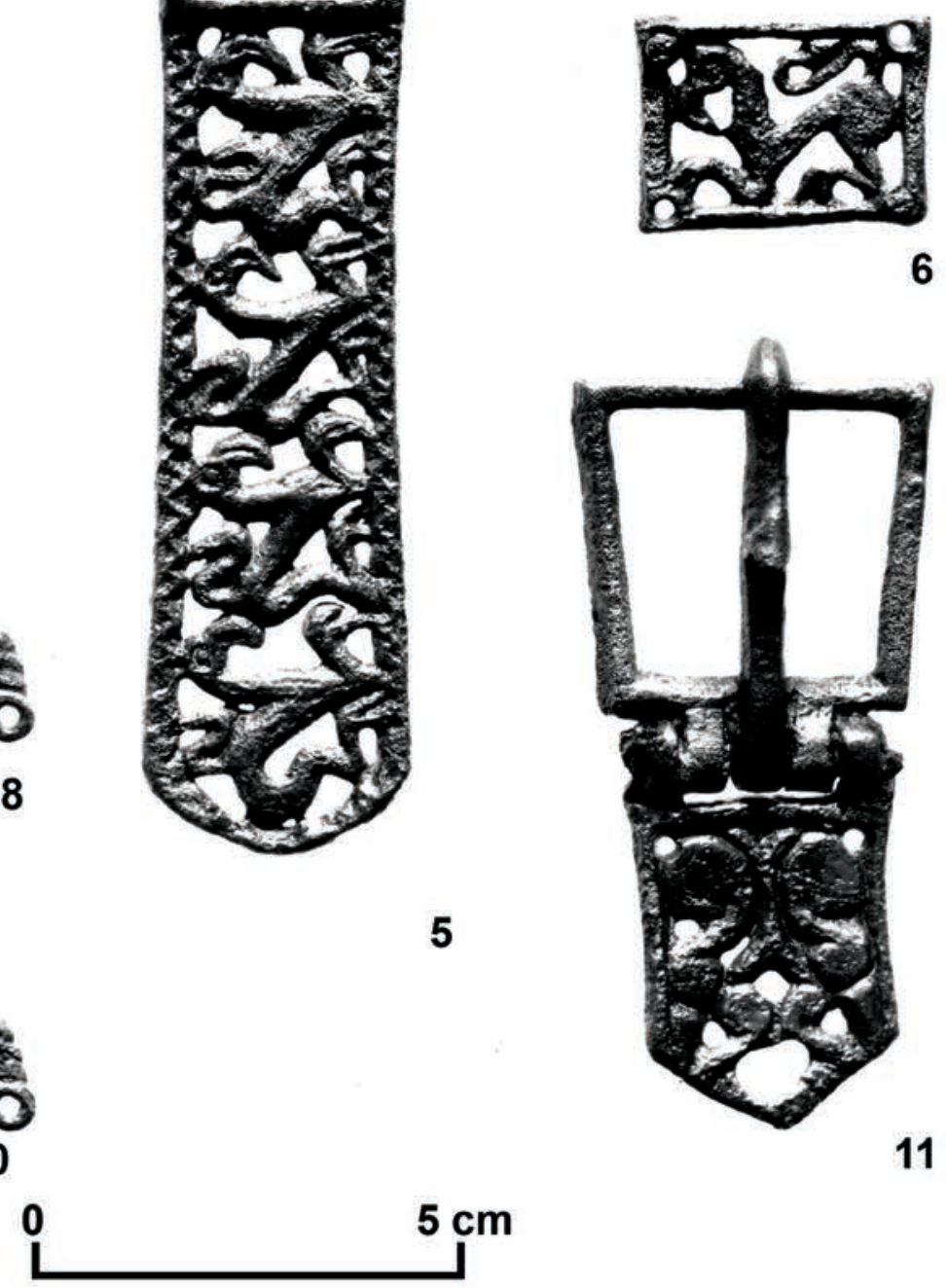


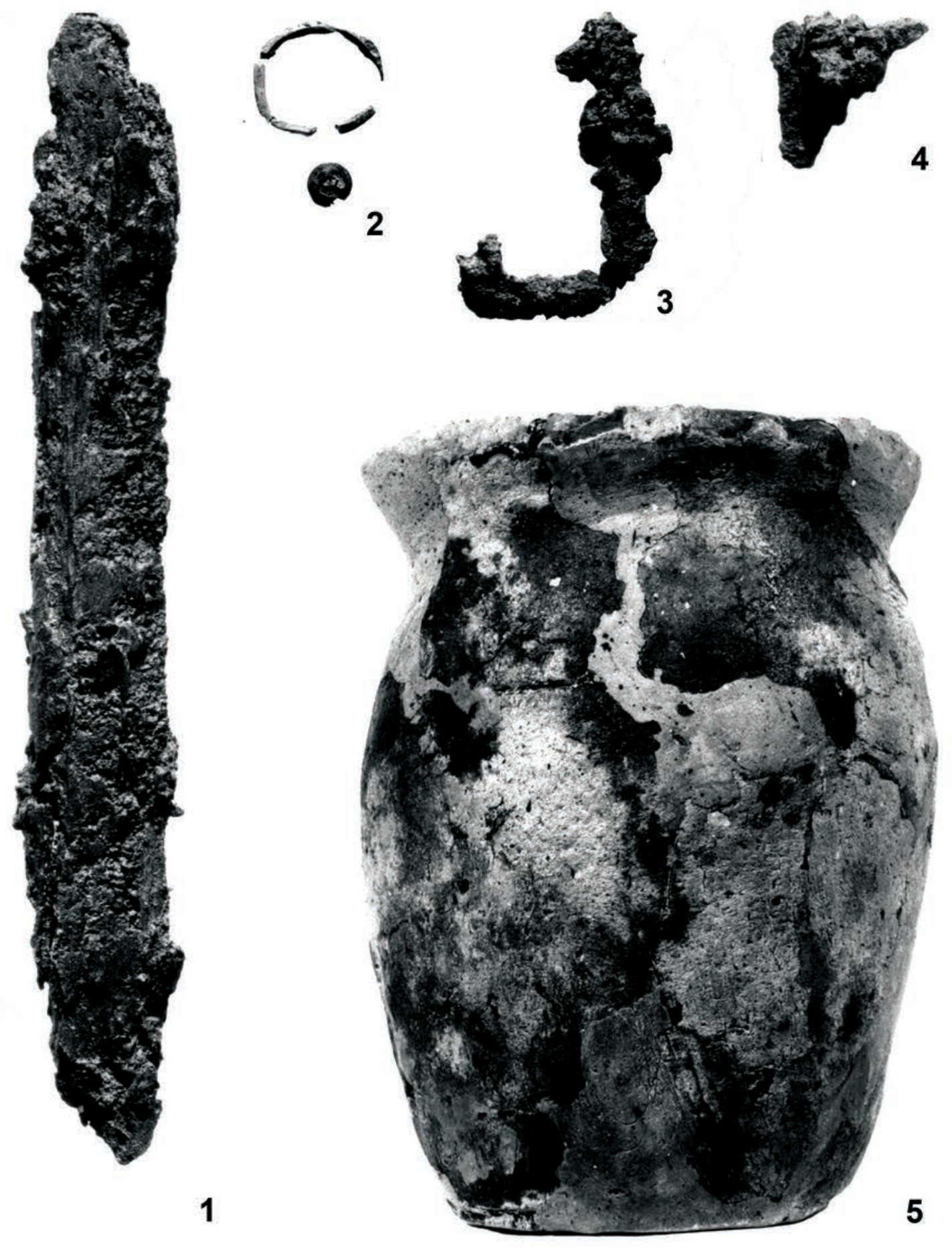

V. tábla. A Szabadszállás-Batthyány utca 10. Sírleletetek a 34. számú sírból

1. vaskés, 2. fülbevaló, 3. vascsat, 4. vastárgy, 5. sírkerámia (Fotó: Kiss Béla) 


\section{Irodalom}

Adam 2002 Szentpéteri, József (Hrsg.): Archäologische Denkmäler der Awarenzeit in Mitteleuropa I-II. Varia Archaeologica Hungarica 13. Budapest, 2002.

Garam 1975 Garam, Éva: The Szebény Cemetery. In: Kovrig, Ilona (ed.): Avar Finds in the Hungarian National Museum. Cemeteries of the Avar Period (567-829) in Hungary 1. Budapest, 1975. 49-120.

FANCSALSZKY 2007 Fancsalszky Gábor: Állat és emberábrázolások a késő avar kori öntött bronz övvereteken. Budapest, 2007.

HoRvátH 1973a Horváth Attila: Szabadszállás-Batthyány u. 8b. Régészeti Füzetek Ser. 1/26. 66.

HoRvÁTH 1973b Horváth Attila: Szabadszállás-Batthyány u. 8b. Archaeologiai Értesítő 100. 269.

HoRvÁTH 2010 Horváth Attila:Vaskori telepnyomok és avar temető feltárása az M0 autópálya soroksár-rétek-dűlői lelőhelyein. Aquncumi Füzetek 16. 152-160.

HoRvÁTH 2017 Horváth M. Attila Későavar temető Soroksár határában. In: Zsidi Paula (szerk.): Kincsek a Város Alatt, Újdonságok a múltból. 2017.04.12.-2017.09.17. Budapest, 2017. 286-287, 293-300.

H. То́тн 1975 H. Tóth Elvira: Szabadszállás-Batthyány u. 10. Archaeologiai Értesítő 102. 304.

H. Tóтн 1975 H. Tóth Elvira: Szabadszállás-Batthyány u. 10. Régészeti Füzetek Ser. I/28. 83.

H. То́тн 1976 H. Tóth Elvira: Szabadszállás-Batthyány u. 10. Archaeologiai Értesítő 103. 298.

H. Тоттн 1976 H. Tóth Elvira: Szabadszállás-Batthyány u. 10. Régészeti Füzetek Ser. I/29. 55.

H. То́тн 1981 H. Tóth Elvira: Sajátos temetkezési szokások a Duna-Tisza közi avarkori temetőkben. Archaeologiai Értesítő 108. 157-193.

H. Тотн 1985 H. Tóth Elvira: Korai avar vezetőréteg családi temetője a kunbábonyi kagán szállásterületén. In: Sztrinkó István (szerk.): Múzeumi Kutatások Bács-Kiskun megyében. Kecskemét, 1984. 10-20.

H. То́тн 1990 H. Tóth Elvira: Négy évtized régészeti kutatásai Bács-Kiskun megyében, 1949-1989. Cumania 12. 81-233.

Pulszky 1881 Pulszky Ferenc: Rekeszes ötvösség Magyarországon. Archaeologiai Értesítő 1. 146-156.

Töвök 1975a Török, Gyula: Kiskőrös-Pohibuj Mackó. In: Kovrig, llona (ed.): Avar Finds in the Hungarian National Museum. Cemeteries of the Avar Period (567-829) in Hungary 1. Budapest, 1975. 283-304.

Töвök 1975b Török, Gyula: The Visznek cemetery. In: Kovrig, llona (ed.): Avar Finds in the Hungarian National Museum. Cemeteries of the Avar Period (567-829) in Hungary 1. Budapest, 1975. 323-345. 